NASA/TM-2004-213218

Reconditioning of Batteries on the International Space Station

Gyan Hajela and Fred Cohen

The Boeing Company, Rocketdyne Power \& Propulsion, Canoga Park, California

Penni Dalton

Glenn Research Center, Cleveland, Ohio 
Since its founding, NASA has been dedicated to the advancement of aeronautics and space science. The NASA Scientific and Technical Information (STI) Program Office plays a key part in helping NASA maintain this important role.

The NASA STI Program Office is operated by Langley Research Center, the Lead Center for NASA's scientific and technical information. The NASA STI Program Office provides access to the NASA STI Database, the largest collection of aeronautical and space science STI in the world. The Program Office is also NASA's institutional mechanism for disseminating the results of its research and development activities. These results are published by NASA in the NASA STI Report Series, which includes the following report types:

- TECHNICAL PUBLICATION. Reports of completed research or a major significant phase of research that present the results of NASA programs and include extensive data or theoretical analysis. Includes compilations of significant scientific and technical data and information deemed to be of continuing reference value. NASA's counterpart of peerreviewed formal professional papers but has less stringent limitations on manuscript length and extent of graphic presentations.

- TECHNICAL MEMORANDUM. Scientific and technical findings that are preliminary or of specialized interest, e.g., quick release reports, working papers, and bibliographies that contain minimal annotation. Does not contain extensive analysis.

- CONTRACTOR REPORT. Scientific and technical findings by NASA-sponsored contractors and grantees.
- CONFERENCE PUBLICATION. Collected papers from scientific and technical conferences, symposia, seminars, or other meetings sponsored or cosponsored by NASA.

- SPECIAL PUBLICATION. Scientific, technical, or historical information from NASA programs, projects, and missions, often concerned with subjects having substantial public interest.

- TECHNICAL TRANSLATION. Englishlanguage translations of foreign scientific and technical material pertinent to NASA's mission.

Specialized services that complement the STI Program Office's diverse offerings include creating custom thesauri, building customized databases, organizing and publishing research results ... even providing videos.

For more information about the NASA STI Program Office, see the following:

- Access the NASA STI Program Home Page at http://www.sti.nasa.gov

- E-mail your question via the Internet to help@sti.nasa.gov

- Fax your question to the NASA Access Help Desk at 301-621-0134

- Telephone the NASA Access Help Desk at 301-621-0390

- Write to:

NASA Access Help Desk

NASA Center for AeroSpace Information 7121 Standard Drive

Hanover, MD 21076 
NASA/TM-2004-213218

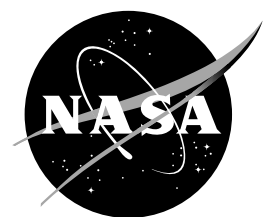

\section{Reconditioning of Batteries on the International Space Station}

Gyan Hajela and Fred Cohen

The Boeing Company, Rocketdyne Power \& Propulsion, Canoga Park, California

Penni Dalton

Glenn Research Center, Cleveland, Ohio

Prepared for the

Second International Energy Conversion Engineering Conference

sponsored by the American Institute of Aeronautics and Astronautics

Providence, Rhode Island, August 16-19, 2004

National Aeronautics and

Space Administration

Glenn Research Center 
This report is a formal draft or working paper, intended to solicit comments and ideas from a technical peer group.

This report contains preliminary
findings, subject to revision as
analysis proceeds.

Available from

NASA Center for Aerospace Information 7121 Standard Drive

Hanover, MD 21076
National Technical Information Service 5285 Port Royal Road Springfield, VA 22100 


\title{
Reconditioning of Batteries on the International Space Station
}

\author{
Gyan Hajela and Fred Cohen \\ The Boeing Company \\ Rocketdyne Power \& Propulsion \\ Canoga Park, California 91309 \\ Penni Dalton \\ National Aeronautics and Space Administration \\ Glenn Research Center \\ Cleveland, Ohio 44135
}

\section{Summary}

Primary source of electric power for the International Space Station (ISS) is the photovoltaic module (PVM). At assembly complete stage, the ISS will be served by 4 PVMs. Each PVM contains two independent power channels such that one failure will result in loss of only one power channel. During early stages of assembly, the ISS is served by only one PVM designated as P6. Solar arrays are used to convert solar flux into electrical power. Nickel hydrogen batteries are used to store electrical power for use during periods when the solar input is not adequate to support channel loads. Batteries are operated per established procedures that ensure that they are maintained within specified temperature limits, charge current is controlled to conform to a specified charge profile, and battery voltages are maintained within specified limits. Both power channels on the PVM P6 have been operating flawlessly since December 2000 with 100 percent power availability. All components, including batteries, are monitored regularly to ensure that they are operating within specified limits and to trend their wear out and age effects. The paper briefly describes the battery trend data. Batteries have started to show some effects of aging and a battery reconditioning procedure is being evaluated at this time. Reconditioning is expected to reduce cell voltage divergence and provide data that can be used to update the state of charge (SOC) computation in the software to account for battery age. During reconditioning, each battery, one at a time, will be discharged per a specified procedure and then returned to a full state of charge. The paper describes the reconditioning procedure and the expected benefits. The reconditioning procedures have been thoroughly coordinated by all affected technical teams and approved by all required boards. The reconditioning is tentatively scheduled for September 2004.

\section{Introduction}

The ISS is an earth-orbiting facility supporting permanent human habitation for conducting research and science experiments in a micro-gravity environment. Electrical power for the ISS is provided by the photovoltaic module (PVM). At assembly complete, the ISS will have four PVMs, but at this time (Assembly Stage 11A) the ISS has only one PVM designated P6. All PVMs are essentially identical as far as their electrical power generation, storage and distribution is concerned.

PVM P6 consists of two independent and almost identical primary power channels (PPC) 2B and 4B. Figure 1 shows only the PPC 4B.

As the ISS orbits around the earth, it goes through insolation (sun) and eclipse (shade) periods. During insolation periods, the solar array wing (SAW) converts solar flux into electrical power using photovoltaic cells. The sequential shunt unit (SSU) regulates the voltage and current output of the SAW. 
Power flows through the beta gimbal assembly (BGA) to the direct current switching unit (DCSU), which provides power to the battery charge/discharge units (BCDU), dc-to-dc converter unit (DDCU), and the primary power port.

During insolation periods, when the SAW output is more than the loads connected to the primary power bus, batteries are charged via BCDUs. During eclipse periods, when SAW output is insufficient to satisfy loads, batteries are discharged through the BCDUs.

\section{Battery Design Description}

Each battery consists of two orbit replaceable units (ORU) connected in series. Each battery ORU consists of 38 independent pressure vessel nickel-hydrogen battery cells connected in series, figure 2, for a total battery compliment of 76 cells. Each battery is designed for a nameplate capacity of $81 \mathrm{Ah}$. Battery orbital design life is 6.5 years. Instrument monitoring consists of:

1) Temperature: Nine thermistors in each ORU, four of which are used for battery thermal control and state of charge (SOC) computations.

2) Pressure: Four cells in each ORU are monitored. The average of these four pressures is used to compute battery SOC.

3) Voltage of each cell is monitored and used for fault detection and isolation.

4) Voltage of each ORU and voltage and current for each battery are monitored for health status of a power channel and controls.

\section{Battery Operation}

Each battery charges and discharges through its BCDU. When the solar array output is more than that needed to support the channel loads, excess power can be used to charge batteries. When solar array output is insufficient to support the loads connected to that channel, the BCDUs transition to discharge mode and discharge batteries to support channel loads.

Maximum charge current is limited by the software, in the PV controller unit (PVCU), on the basis of the battery state of charge (SOC). The software contains a routine that monitors battery cell pressure and temperature and uses that data to compute battery SOC. The software contains a charge profile that determines the maximum charge current based on the SOC, figure 3 . The battery charge current is reduced to $2 \mathrm{~A}$ as the battery SOC approaches 100 percent.

The software uses parameters that are inputs via a pre-positioned parameter list (PPL), or a data file. The current PPL parameters are for new batteries. These parameters include cell pressure at SOC of 0 percent and the slope of the pressure vs SOC line, figure 4. Cell pressure at 0 percent SOC increases as batteries age but the slope remains unchanged.

\section{Current Battery Health Status}

PVM P6 has been operating with 100 percent power availability since December 2000. All PVM components are routinely monitored and their health status / performance is documented and reported, however, the focus of this paper is the batteries. The batteries have been operating very well since their start-up over $3 \frac{1}{2}$ years ago. Battery health monitoring, using on-orbit data, includes the following parameters and flag values: 
1) Inter-cell Temperature. This parameter is monitored by four strategically located representative cell sleeve temperatures. Batteries and thermal control system are designed to maintain a cell-to-cell temperature gradient of less than $3{ }^{\circ} \mathrm{C}$ within a battery. Figure 5 shows the inter-cell temperature variance (within the 8 monitored cells) for battery 2B1. Table I shows the inter-cell temperature variance for all batteries and the trend since start-up.

2) ORU Voltage. For normal battery operation, the ORU voltage difference for a battery should remain at less than $2 \mathrm{~V}$. Figure 5 shows the ORU voltage difference for battery $2 \mathrm{~B} 1$. Table II shows the ORU voltage difference for all batteries and the trend since start-up.

3) Cell Voltage. For normal battery operation, the cell voltage variance within a battery should remain less than $50 \mathrm{mV}$. Figure 5 shows the cell voltage variance for battery $2 \mathrm{~B} 1$. Table III shows the cell voltage variance for all batteries and the trend since start-up.

4) ORU Pressure. For normal battery operation, the average ORU pressure difference within a battery should remain less than 100 psi. Figure 5 shows the ORU pressure variance for battery $2 \mathrm{~B} 1$. Table IV shows the ORU pressure variance for all batteries and the trend since start-up.

On-orbit data shows that all batteries are operating within their allowable and expected operating range with the exception of the pressure variance for battery 4B2. No limits were specified for the ORU pressure variance but it was expected to remain less than $100 \mathrm{psi}$. End of discharge depth of discharge (DOD) ranged from 20 to 25 percent which is well within the design to value of 35 percent DOD.

Battery 4B2 ORU pressure variance anomaly has been analyzed and is understood to be due to age differences in the two ORUs that make the battery. Efforts were made to re-initialize the battery to help equalize the cells but such efforts showed only short-term benefits. The ORU pressure variance was at one time as high as $170 \mathrm{psi}$ but has been coming down gradually as both ORUs continue to age, with a present pressure variance of about 100 psi. The negative effects of ORU pressure variance are understood, with a maximum allowable variance identified. The capacity of battery 4B2 is lower than the capacity of other batteries on PVM P6 because the battery capacity is controlled by the lower capacity ORU. Battery 4B2 capacity was measured in February 2002 and was found to be approximately $56 \mathrm{Ah}$. Note that due to intermittent telemetry data dropouts, this capacity is estimated and could actually be somewhat higher. Using end of charge pressure measurements, the capacity of other batteries is estimated to be approximately $81 \mathrm{Ah}$. Please note that a capacity of $50 \mathrm{Ah}$ is required to satisfy power performance requirements (continuous plus contingency power requirements) thus battery 4B2 is capable of satisfying all power requirements.

\section{Effects of Age}

As batteries age on orbit, they go through three significant changes, as described below:

1) Pressure at 100 percent SOC. As batteries age, the average cell pressure at 0 percent rises while the rate of change of pressure with SOC remains the same. This introduces an error in the SOC determination in the software and hence the charge current computed by the software, figure 4 . If the batteries are not fully charged then they have lower capacity and they may not be able to support high loads or contingency situations. Battery reconditioning, as described below, can be utilized to determine pressure at 0 percent SOC and the PPL parameters can be modified such that the batteries can be fully charged as they age.

2) Cell Divergence. As batteries age their cells start to diverge. Such divergence is indicated by temperature, voltage or pressure variances between cells. Data for cell divergence is regularly monitored by plots shown in figure 5 . Though battery cells do not show abnormal divergence, at this time, battery reconditioning is expected to minimize cell divergence. 
3) Capacity loss. As batteries age, the available capacity is reduced. Eventually, capacity will reduced to the point that mission loads cannot be met. Battery reconditioning also enables tracking of battery capacity with time.

\section{Reconditioning}

Battery reconditioning essentially consists of fully discharging battery and then fully charging them. Fully discharging a battery and holding it at that state for some time helps to reduce cell divergence at low end and provide cell pressure data at 0 percent SOC. Full charge of battery is accomplished by slightly overcharging battery, using low charge current. This helps to minimize cell divergence at high end.

It is recommended that battery reconditioning be performed every 2 years, more frequently if the cell divergence is detected, to update pressure data and to reduce cell divergence. Battery reconditioning is now overdue.

Procedure for battery reconditioning is described below:

1) Select a battery to recondition. All batteries will be reconditioned individually. Ensure that electrical loads on the power channel are in the range of 6 to $9 \mathrm{~kW}$. The power channel hardware is designed to provide full power capability, $\sim 11 \mathrm{~kW}$, with one battery out of service.

2) Inhibit charging of the selected battery. Discharge the battery using channel loads without charging it. Continue until the voltage of one of the ORU drops to $38 \mathrm{~V}$ or one of the cell voltage drops to $0.4 \mathrm{~V}$. Monitor and record Ah discharged during this step as battery capacity prior to reconditioning. Monitor and record cell voltage data during the discharge as an indicator of battery health prior to reconditioning.

3) Disconnect the battery from the BCDU by opening the Fault Isolator (FI) between the battery and the BCDU. Engage the drain resistor in each battery ORU to discharge ORUs individually. Monitor cell voltages and record the time when any one cell reaches $0.1 \mathrm{~V}$. Keep the drain resistor engaged for another 24 hours or until all cell voltages drop below $0.1 \mathrm{~V}$. Record average cell pressure. This data will be used to update the battery PPL for battery age.

4) After both ORUs have completed the step above, the battery is ready for re-start. Battery re-start will be performed using a start-up charge profile, figure 6 .

5) Start charging the battery and keep track of Ah input to the battery. Continue to charge until the total $\mathrm{Ah}$ to the battery reaches $103 \mathrm{~A}$. It is acceptable to continue to charge to the end of the insolation period after the battery reaches the $103 \mathrm{Ah}$.

6) Inhibit charge of the battery. Enable discharge the battery using channel loads without charging it. Continue until the voltage of one of the ORU drops to $38 \mathrm{~V}$ or one of the cell voltage drops to $0.4 \mathrm{~V}$. Inhibit discharge. Keep track of the Ah discharged and the record total Ah discharged during this step as battery capacity post reconditioning. Comparison of pre- and post-reconditioning battery capacity will an indicator of benefits of reconditioning.

7) Monitor and record cell voltage data during the discharge. Comparison of pre- and postreconditioning cell voltage divergence will quantify benefits of reconditioning.

8) Start charging the battery and keep track of Ah input to the battery. Continue to charge until the total Ah to the battery reaches $103 \mathrm{~A}$. It is acceptable to continue to charge to the end of the insolation period after the battery reaches the $103 \mathrm{Ah}$.

9) Upload the PPL with normal operations charge profile, figure 3. Enable discharge.

10) Update SOC computation PPL for battery age and upload it as soon as possible (target within one week of completion of reconditioning). 


\section{Schedule}

Total time to recondition a battery is estimated to be 4 to 5 days so it is recommended that it be scheduled at the start of the week so that the battery could be returned to normal operation before the end of the week.

It is recommended that the reconditioning be scheduled for a period when the orbit beta angle is in the range of -40 to +40 degree. This range of beta angles ensures sufficient length of the eclipse period such that battery discharge, using channel loads, could be accomplished within reasonable time.

Battery reconditioning has been thoroughly coordinated with all affected teams and has been briefed to and approved by various Boards. The on-orbit reconditioning is tentatively scheduled for September 2004.

\section{Conclusion}

Batteries on the ISS continue to operate normally and satisfy all performance requirements. However, the batteries are accumulating on-orbit operational time and they are overdue for reconditioning. The reconditioning will ensure that the batteries will be fully charged as they age and the reconditioning will help reduce cell divergence. Reconditioning procedures have been developed and thoroughly coordinated with all affected teams. The procedure has been briefed to and approved by appropriate Boards. 


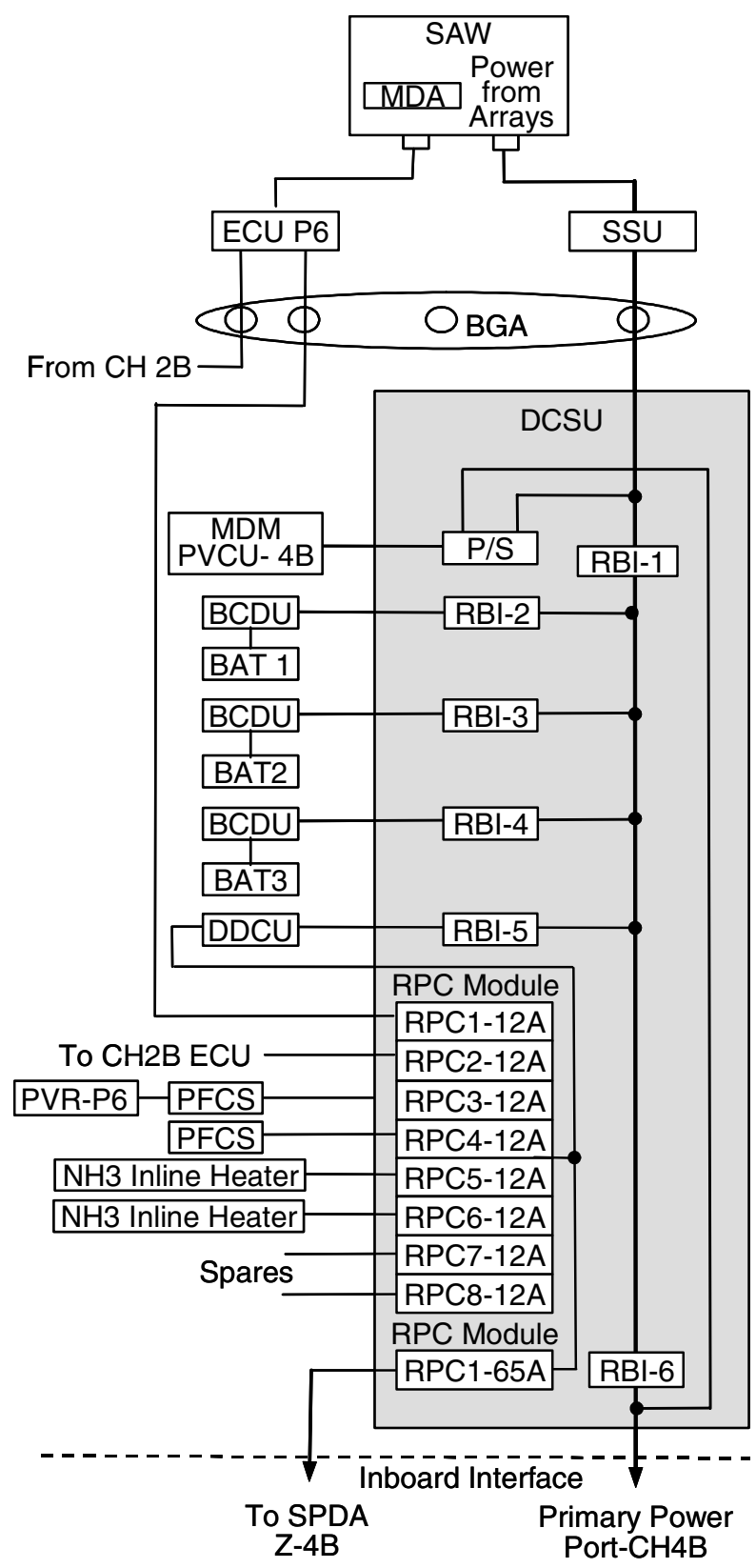

Figure 1.-P6 photovoltaic module power diagram (power channel 4B). 


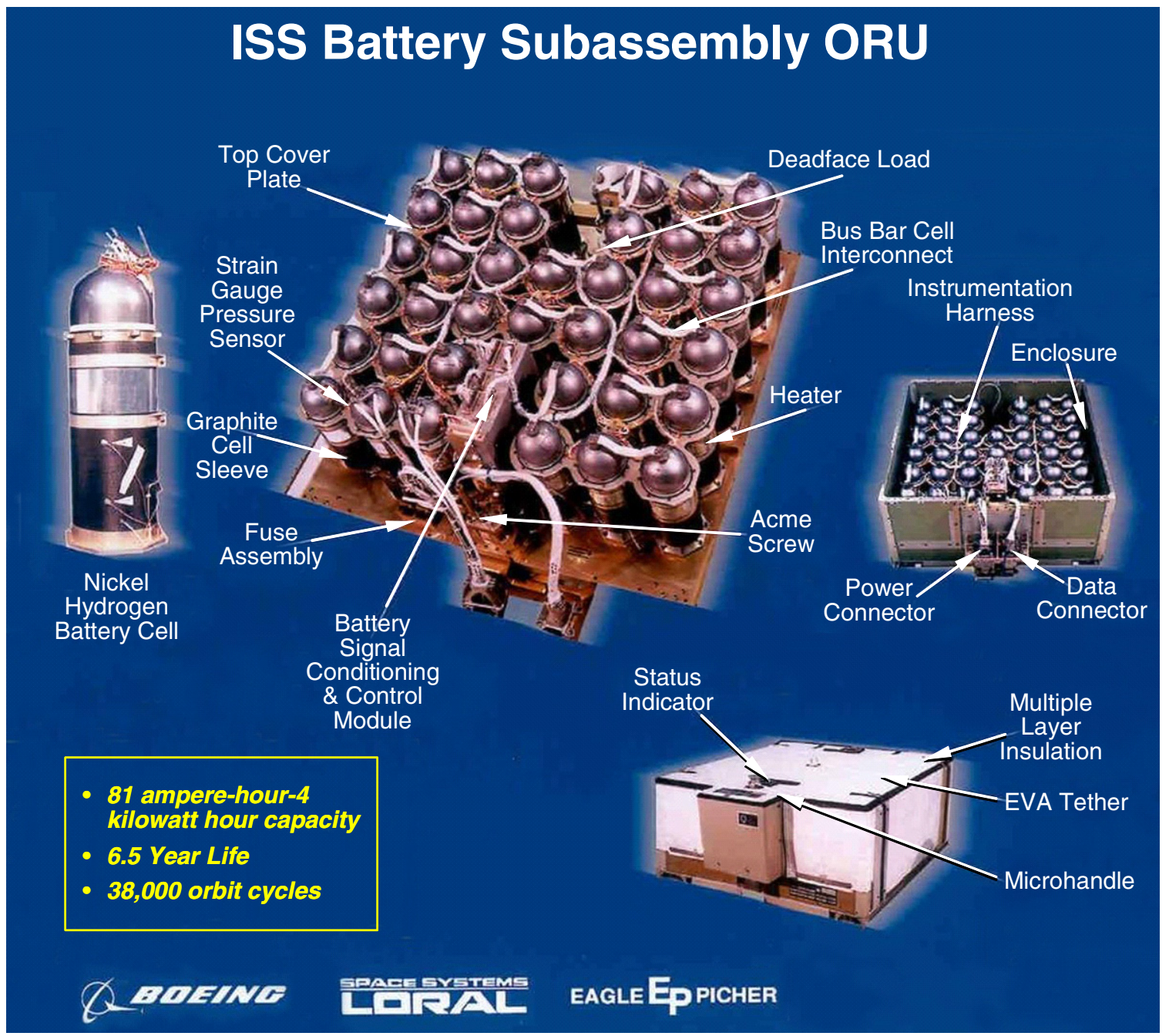

Figure 2.-Battery orbit replacement unit. 


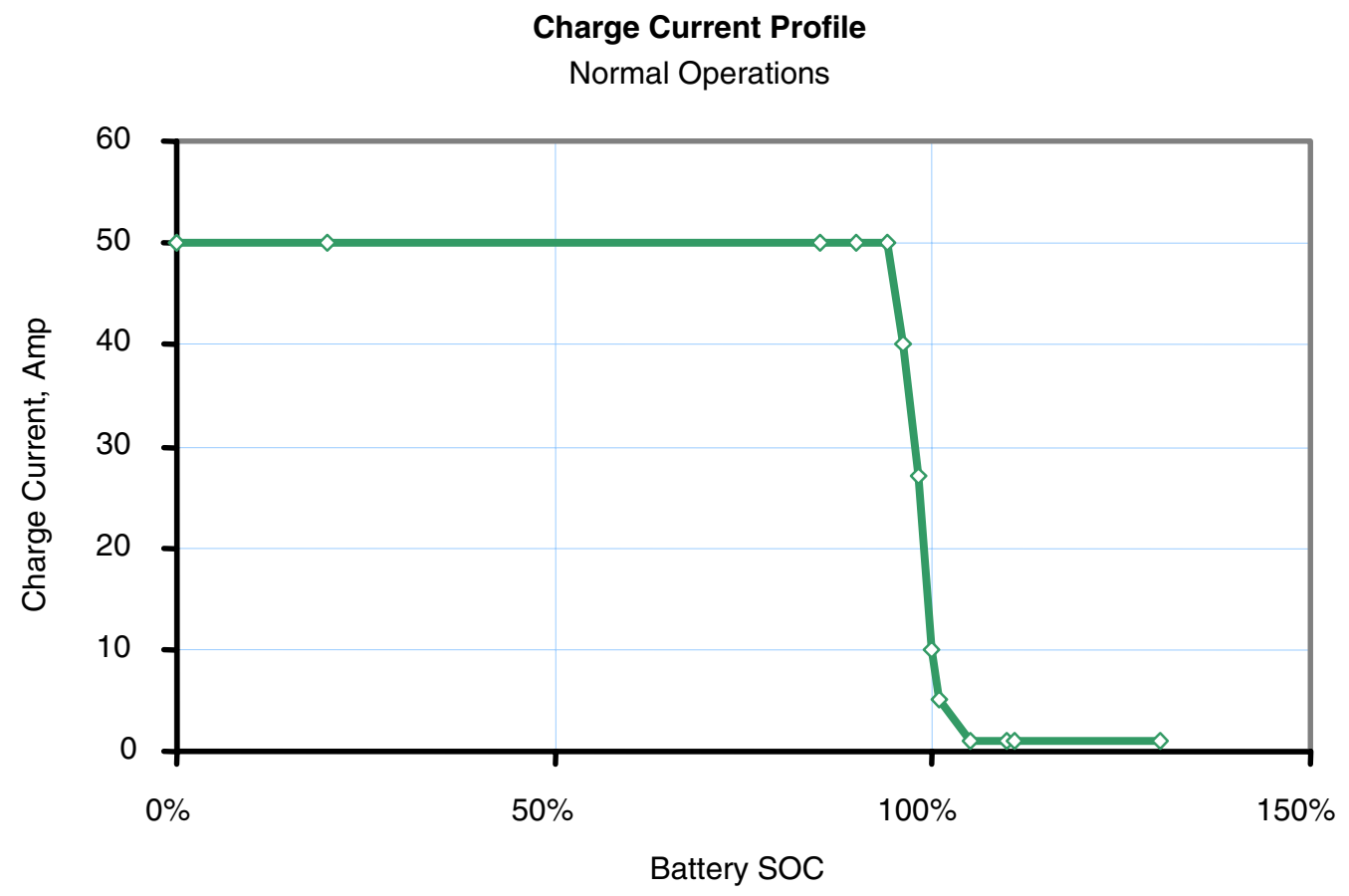

Figure 3.-Battery charge profile-normal operations.

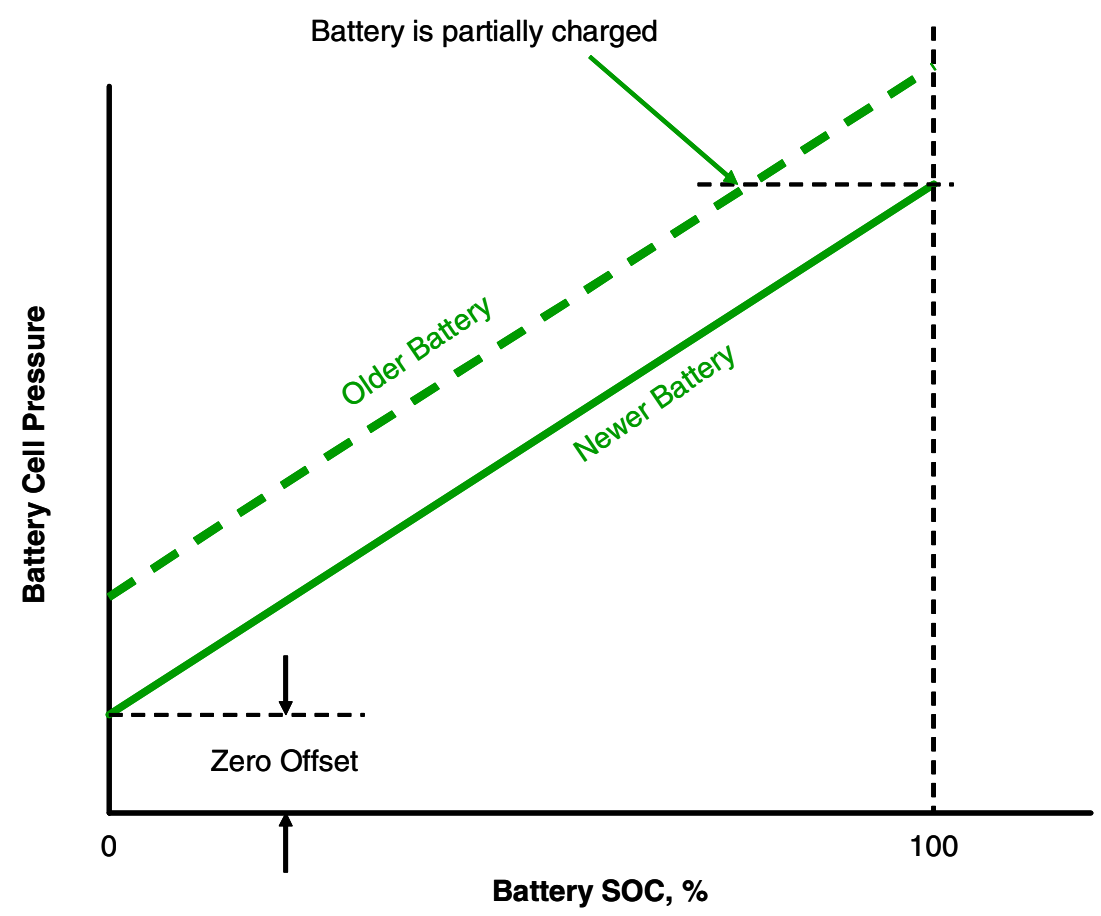

Figure 4.-Battery cell pressure variance with age. 

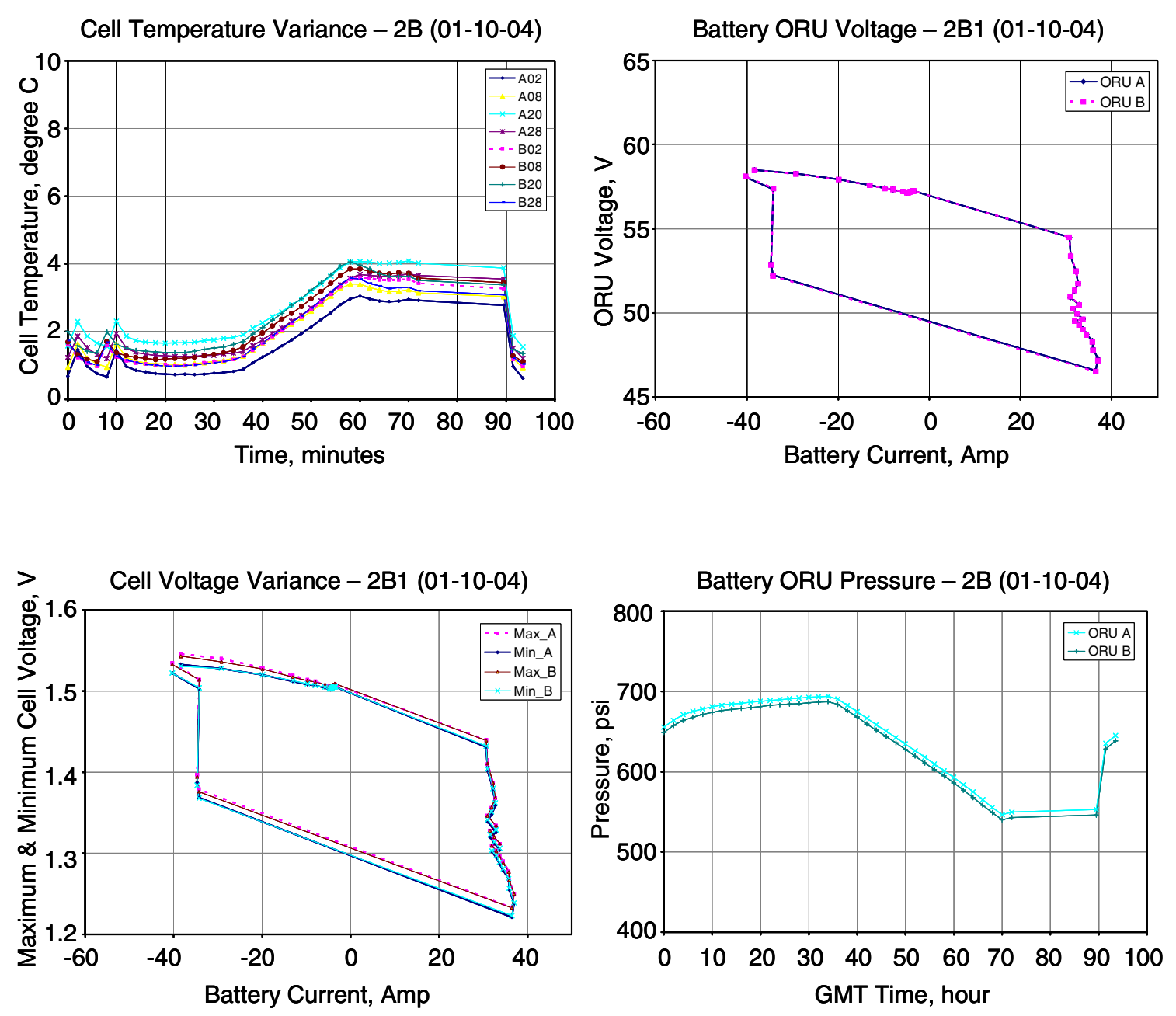

Figure 5.-On-orbit data plots for battery 2B1. 


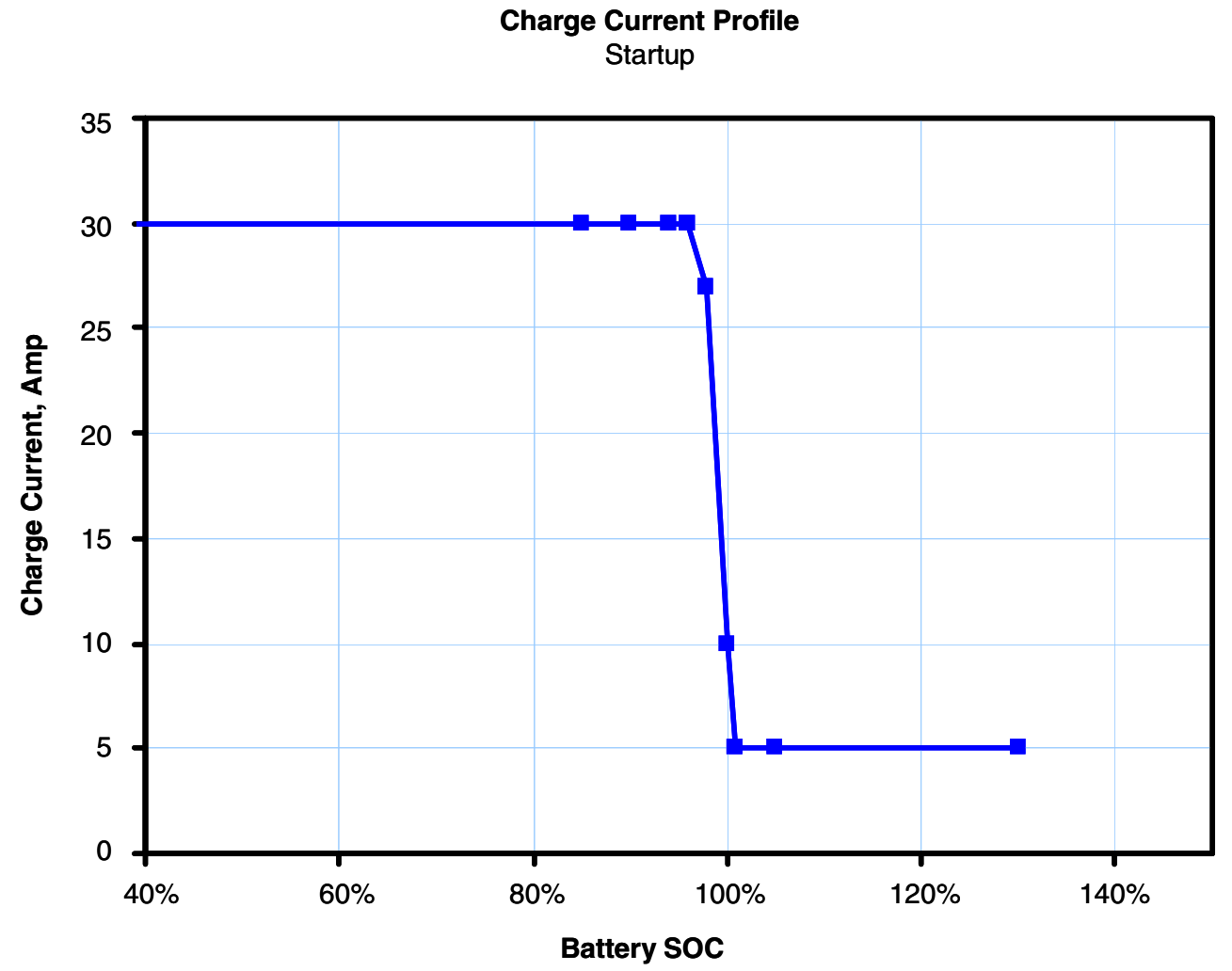

Figure 6.-Start-up charge profile. 
TABLE I.-BATTERY INTER_CELL_DELTA_T TREND

All Temperatures in Degree $C$

\begin{tabular}{|c|c|c|c|c|}
\hline \multirow{2}{*}{ Battery } & \multicolumn{4}{|c|}{ Monitoring Date } \\
\cline { 2 - 5 } & Sep 01 & Mar 02 & Jan 03 & Jan 04 \\
\hline 2B1 & $<1.0$ & $<1.5$ & $<1.5$ & $<1.5$ \\
\hline 2B2 & $<1.5$ & $<3.0$ & $<3.0$ & $<3.0$ \\
\hline 2B3 & $<1.5$ & $<2.0$ & $<1.5$ & $<1.5$ \\
\hline 4B1 & $<1.5$ & $<2.0$ & $<2.0$ & $<2.0$ \\
\hline 4B2 & $<1.5$ & $<2.0$ & $<2.0$ & $<1.5$ \\
\hline 4B3 & $<1.5$ & $<2.0$ & $<2.0$ & $<2.0$ \\
\hline
\end{tabular}

TABLE II.-BATTERY ORU_DELTA_V TREND

\begin{tabular}{|c|c|c|c|c|}
\hline \multicolumn{5}{|c|}{ All Voltages are in Volts } \\
\hline \multirow{2}{*}{ Battery } & \multicolumn{5}{|c|}{ Monitoring Date } \\
\cline { 2 - 5 } & Sep 01 & Mar 02 & Jan 03 & $<$ Jan 04 \\
\hline 2B1 & $<1.0$ & $<1.0$ & $<1.0$ & $<1.0$ \\
\hline 2B2 & $<1.0$ & $<1.0$ & $<1.0$ & $<1.0$ \\
\hline 2B3 & $<1.0$ & $<1.0$ & $<1.0$ & $<1.0$ \\
\hline 4B1 & $<1.0$ & $<1.0$ & $<1.0$ & $<1.0$ \\
\hline 4B2 & $<1.0$ & $<1.0$ & $<1.0$ & $<1.0$ \\
\hline 4B3 & $<1.0$ & $<1.0$ & $<1.0$ & \\
\hline
\end{tabular}

TABLE III.-BATTERY CELL_DELTA_V TREND

\begin{tabular}{|c|c|c|c|c|}
\hline \multicolumn{5}{|c|}{ All Voltages in mV } \\
\hline \multirow{2}{*}{ Battery } & \multicolumn{5}{|c|}{ Monitoring Date } \\
\cline { 2 - 5 } & Sep 01 & Mar 02 & Jan 03 & Jan 04 \\
\hline 2B1 & $<30$ & $<30$ & $<30$ & $<20$ \\
\hline 2B2 & $<30$ & $<30$ & $<30$ & $<30$ \\
\hline 2B3 & $<20$ & $<20$ & $<20$ & $<20$ \\
\hline 4B1 & $<30$ & $<20$ & $<20$ & $<40$ \\
\hline 4B2 & $<40$ & $<40$ & $<40$ & $<20$ \\
\hline 4B3 & $<20$ & $<20$ & $<30$ & $<$ \\
\hline
\end{tabular}

TABLE IV.-BATTERY ORU DELTA PRESSURE

\begin{tabular}{|c|c|c|c|c|}
\hline \multicolumn{5}{|c|}{ All Pressures in psi } \\
\hline \multirow{2}{*}{ Battery } & \multicolumn{5}{|c|}{ Monitoring Date } \\
\cline { 2 - 5 } & Sep 01 & Mar 02 & Jan 03 & Jan 04 \\
\hline 2B1 & $<10$ & $<10$ & $<10$ & $<10$ \\
\hline 2B2 & $<30$ & $<30$ & $<35$ & $<35$ \\
\hline 2B3 & $<10$ & $<20$ & $<10$ & $<10$ \\
\hline 4B1 & $<10$ & $<20$ & $<10$ & $<120$ \\
\hline 4B2 & $<150$ & $<150$ & $<150$ & $<10$ \\
\hline 4B3 & $<10$ & $<20$ & $<10$ & \\
\hline
\end{tabular}


Public reporting burden for this collection of information is estimated to average 1 hour per response, including the time for reviewing instructions, searching existing data sources, gathering and maintaining the data needed, and completing and reviewing the collection of information. Send comments regarding this burden estimate or any other aspect of this collection of information, including suggestions for reducing this burden, to Washington Headquarters Services, Directorate for Information Operations and Reports, 1215 Jefferson Davis Highway, Suite 1204, Arlington, VA 22202-4302, and to the Office of Management and Budget, Paperwork Reduction Project (0704-0188), Washington, DC 20503.

\begin{tabular}{|l|l|l|}
\hline 1. AGENCY USE ONLY (Leave blank) & $\begin{array}{c}\text { 2. REPORT DATE } \\
\text { September } 2004\end{array}$ & $\begin{array}{r}\text { 3. REPORT TYPE AND DATES COVERED } \\
\text { Technical Memorandum }\end{array}$ \\
\hline
\end{tabular}

\section{TITLE AND SUBTITLE} 5. FUNDING NUMBERS

Reconditioning of Batteries on the International Space Station

\section{AUTHOR(S)}

WBS-22-335-14-03-11

Gyan Hajela, Fred Cohen, and Penni Dalton

\section{PERFORMING ORGANIZATION NAME(S) AND ADDRESS(ES)}

National Aeronautics and Space Administration

John H. Glenn Research Center at Lewis Field

Cleveland, Ohio 44135-3191
8. PERFORMING ORGANIZATION REPORT NUMBER

E-14725

\section{SPONSORING/MONITORING AGENCY NAME(S) AND ADDRESS(ES)}

National Aeronautics and Space Administration

Washington, DC 20546-0001

10. SPONSORING/MONITORING AGENCY REPORT NUMBER

NASA TM-2004-213218

AIAA-2004-5655

\section{SUPPLEMENTARY NOTES}

Prepared for the Second International Energy Conversion Engineering Conference sponsored by the American Institute of Aeronautics and Astronautics, Providence, Rhode Island, August 16-19, 2004. Gyan Hajela and Fred Cohen, The Boeing Company, Rocketdyne Power \& Propulsion, 6633 Canoga Avenue, Canoga Park, California 91309; and Penni Dalton, NASA Glenn Research Center. Responsible person, Penni Dalton, organization code 6910, 216-433-5223.

12a. DISTRIBUTION/AVAILABILITY STATEMENT

\section{2b. DISTRIBUTION CODE}

Unclassified - Unlimited

Subject Category: 20

Distribution: Nonstandard

Available electronically at http://gltrs.grc.nasa.gov

This publication is available from the NASA Center for AeroSpace Information, 301-621-0390.

\section{ABSTRACT (Maximum 200 words)}

Primary source of electric power for the International Space Station (ISS) is the photovoltaic module (PVM). At assembly complete stage, the ISS will be served by 4 PVMs. Each PVM contains two independent power channels such that one failure will result in loss of only one power channel. During early stages of assembly, the ISS is served by only one PVM designated as P6. Solar arrays are used to convert solar flux into electrical power. Nickel hydrogen batteries are used to store electrical power for use during periods when the solar input is not adequate to support channel loads. Batteries are operated per established procedures that ensure that they are maintained within specified temperature limits, charge current is controlled to conform to a specified charge profile, and battery voltages are maintained within specified limits. Both power channels on the PVM P6 have been operating flawlessly since December 2000 with 100 percent power availability. All components, including batteries, are monitored regularly to ensure that they are operating within specified limits and to trend their wear out and age effects. The paper briefly describes the battery trend data. Batteries have started to show some effects of aging and a battery reconditioning procedure is being evaluated at this time. Reconditioning is expected to reduce cell voltage divergence and provide data that can be used to update the state of charge (SOC) computation in the software to account for battery age. During reconditioning, each battery, one at a time, will be discharged per a specified procedure and then returned to a full state of charge. The paper describes the reconditioning procedure and the expected benefits. The reconditioning procedures have been thoroughly coordinated by all affected technical teams and approved by all required boards. The reconditioning is tentatively scheduled for September 2004.

14. SUBJECT TERMS

Space station power; Batteries; Nickel hydrogen batteries PAGES 17

\begin{tabular}{|c|c|c|}
\hline $\begin{array}{c}\text { 17. SECURITY CLASSIFICATION } \\
\text { OF REPORT }\end{array}$ & $\begin{array}{c}\text { 18. SECURITY CLASSIFICATION } \\
\text { OF THIS PAGE } \\
\text { Unclassified }\end{array}$ & $\begin{array}{c}\text { 19. SECURITY CLASSIFICATION } \\
\text { OF ABSTRACT } \\
\text { Unclassified }\end{array}$ \\
\hline
\end{tabular}



